\title{
Penerapan Model Pembelajaran Kooperatife Tipe Reciprocal Teaching untuk Meningkatkan Keterampilan Membaca Intensif pada Siswa MTs Darul Ulum Cepala
}

\author{
Molek $^{1}$, Susan Neni Triani ${ }^{2}$, Lili Yanti ${ }^{3}$ \\ STKIPSingkawang, Singkawang, Indonesia \\ kakdemolek@gmail.com¹ ${ }^{1}$, susannenitriani@gmail.com², liliyantiana18@gmail.com³
}

\begin{tabular}{ll}
\hline \hline Keywords : & ABSTRACT \\
Kooperatif Reciprocal & Penelitian ini bertujuan untuk: (1) Mengetahui keterlaksanaan \\
Teaching, Keterampilan & proses pembelajaran kooperatif tipe reciprocal teaching, (2) \\
Membaca Intensif & Mengtahui seberapa besar peningkatan hasil belajar siswa \\
& teaching, model pembelajaran kooperatif tipe reciprocal \\
& tehadapnditerapkanny model model pembelajaran kooperatif \\
tipe reciprocal teaching pada materi mengungkapkan hal-hal & yang dapat diteladani dari buku biografi dengan membaca \\
intensif. Bentuk penelitian ini pre-eksperimental dengan \\
rancangan one group pretest-posttest design.Dalam \\
rancangan penelitian ini dilakukan pengukuran berupa pretest \\
kemudian diberikan perlakuan dengan jangka waktu tertentu, \\
kemudian dilakukan pengukuran berupa posttest. Instrumen tes \\
berupa tes esai yang telah diuji cobakan dengan reliabilitas \\
sebesar 0,54 kriteria cukup. Berdasarkan perbandingan tes \\
awal (pretest) sebelum perlakuan dan tes akhir (posttest) \\
setelah diberi perlakuan dengan model pembelajaran \\
kooperatif tipe reciprocal teaching diperoleh hasil nilai bahwa \\
nilai posttest lebih tinggi dari nilai pretest, sehingga diperoleh \\
nilai N-Gain sebesar o,53 dengan kriteria sedang. \\
Keterlaksanaan model pembelajaran kooperatif tipe reciprocal \\
teaching pada materimengungkapkan hal-hal yang dapat \\
diteladani dari buku biografi memperoleh nilai sebesar \\
87,865\% kriteria baik sekali. Untuk respon siswa secara \\
keseluruhan terhadap materi mengungkapkan hal-hal yang \\
dapat diteladani dari buku biografi menggunakan model \\
pembelajaran kooperatif tipe reciprocal teachingdengan \\
persentase sebesar 62,85\%. Dengan demikian, dapat \\
disimpulkan bahwa pelaksanaan materi mengungkapkan hal- \\
halyang dapat diteladani dari buku biografi dengan membaca \\
intensif melalui penerapan model pembelajaran kooperatif tipe \\
reciprocal teaching di kelas VII B MTs Darul Ulum Cepala \\
dapat dikatakan meningkat.
\end{tabular}




\section{PENDAHULUAN}

Tujuan pendidikan adalah mengembangkan kemampuan dan membentuk watak, kepribadian serta peradapan yang bermartabat dalam hidup dan kehidupan.Pembelajaran bahasa Indonesia dalam pendidikan sangat penting bagi kehidupan.Pembelajaran bahasa Indonesia terdiri atas dua jenis keterampilan yaitu keterampilan berbahasa dan bersastra.Tarigan (2008:1) bahwa keterampilan berbahasa mencakup empat komponen yaitu, keterampilan menyimak, keterampilan berbicara, keterampilan membaca, dan keterampilan menulis. Keempat keterampilan tersebut memiliki hubungan yang sangat erat antara satu sama lain. Dilihat dari sifatnya, keterampilan menyimak dan membaca bersifat reseptif yaitu menerima atau memahami pesan yang disampaikan oleh pembicara atau penulis, sedangkan berbicara dan menulis bersifat produktif, artinya menghasilkan pembicaraan atau tulisan.

Membaca adalah suatu proses yang dilakukan serta dipergunakan oleh pembaca untuk memperoleh pesan yang hendak disampaikan oleh penulis melalui media kata-kata/bahasa tulis (Tarigan, 2015:7). Membaca adalah proses perubahan bentuk lambang/tanda/tulisan menjadi wujud bunyi yang bermakna (Dalman, 2013:7). Membaca merupakan perbuatan yang dilakukan berdasarkan kerja sama, selain itu membaca merupakan penangkapan dan pemahaman ide, aktivitas pembaca yang diiringi curahan siswa dalam menghayati naskah bacaan (Saddhono, 2012:64).

Membaca intensif dianggap sebagai salah satu kunci pemerolehan ilmu pengetahuan karena penekanannya adalah persoalan pemahaman yang mendalam, pemahaman ide-ide naskah dari pokok sampai ke ide-ide penjelas dan hal-hal yang rinci, sampai kerelung-relungnya.Dilakukan secara lambat dan boleh dilakukan berulang-ulang, agar pesan tertulisnya lebih merasuk ke otak dan hati.Membaca intensif adalah studi saksama, telaah teliti dan penanganan terperinci yang dilaksanakan di dalam kelas terhadap suatu tugas yang pendek kira-kira dua sampai empat halaman setiap hari.

Berdasarkan hasil wawancara dengan guru mata pelajaran bahasa Indonesia MTs Darul Ulum Cepala yaitu Titia Asyari, S.Pd.I mengungkapkan bahwa Kriteria Ketuntasan Minimal (KKM) mata pelajaran bahasa Indonesia kelas VII adalah 70 . Hasil keterampilan membaca intensif dari dua kelas, siswa kelas VII A berjumlah 24 siswa, 10 atau $42 \%$ siswa tuntas dan 14 atau 58\% siswa tidak tuntas. Siswa kelas VII B berjumlah 28 siswa, 7 atau $29 \%$ siswa tuntas dan 21 atau $75 \%$ siswa tidak tuntas. Dapat disimpulkan bahwa hasil keterampilan membaca intensif yang paling banyak tidak tuntas adalah kelas VII B. Jadi, dari data tersebut yang akan dilakukan penelitian adalah kelas VII B, karena rata-rata nilainya masih rendah.

Masalah yang terjadi pada siswa dalam materi membaca intensif, khususnya pada kelas VII B, yakni masih banyak pula siswa yang kurang lancar membaca dan kurang berminat dalam membaca, terutama membacakan teks biografi. Siswa masih terlihat malu-malu dan ragu-ragu dalam membacakan teks biografi di depan kelas. Selain itu, siswa juga tidak memperhatikan tanda baca yang terdapat dalam teks tersebut, dan dalam proses pembelajaran pada materi membaca intensif, guru masih menggunakan metode yang bersifat konvensional.

Model pembelajaran adalah suatu rencana atau pola yang dapat digunakan untuk membentuk kurikulum (rencana pembelajaran jangka panjang), merancang bahan-bahan pembelajaran, dan membimbing pembelajaran di kelas atau di settingyang berbeda (Huda, 2014: 73).Sedangkan menurut Ngalimun (2016: 24), "model pembelajaran adalah suatu perencanaan atau suatu pola yang digunakan sebagai pedoman dalam merencanakan pembelajaran di kelas.Sehubungan dengan itu penulis ingin menerapkan Model pembelajaran reciprocal teaching untuk meningkatkan keterampilan membaca intensif.Hal ini bertujuan untuk meningkatkan hasil belajar siswa dengan menggunakan model yang digunakan guru.

Sebelumnya telah dipaparkan di latar belakang mengenai penelitian yang relevan dengan model yang sama tetapi materi berbeda. Penelitian yang dilakukan oleh Muh. Bagus Prasetyo pada tahun 2015 
yang berjudul "Penerapan Model Pembelajaran Reciprocal Teaching Untuk Meningkatkan Kemampuan Membaca Pemahaman Siswa Kelas V SD Negeri Krikilan 1 tahun ajaran 2014/2015". Hasil penelitian tindakan kelas ini menunjukkan bahwa nilai rata-rata kelas tes kemampuan membaca pemahaman pada prasiklus adalah 55,14 dengan ketuntasan klasikal mencapai 28,57\%. Pada siklus I, nilai rata-rata kelas tes membaca pemahaman meningkat menjadi 69,87 dengan ketuntasan klasikal mencapai $57,14 \%$. Pada siklus II, nilai rata-rata kelas tes kemampuan membaca pemahaman meningkat lagi menjadi 83,13 dengan ketuntasan klasikal mencapai 89,29\%. Simpulan penelitian ini menunjukkan bahwa hasil penelitian model pembelajaran Reciprocal Teaching dapat meningkatkan kemampuan membaca pemahaman siswa kelas V SD Negeri Krikilan 1 tahun ajaran 2014/2015.

Berdasarkan hal tersebut,dalam penelitian ini akan diterapkan model pembelajaran reciprocal teaching untuk melihat sejauh mana tingkat keterampilan membaca siswa dalam proses pembelajaran serta membantu meningkatkan kemampuan dalam proses pembelajaran di sekolah maupun di luar sekolah dalam kegiatan sehari-hari siswa.Reciprocal teaching adalah model pembelajaran berupa kegiatan mengajarkan materi kepada teman. Pada model ini siswa berperan sebagai "guru" untuk menyampaikan materi kepada teman-temannya, sementara itu, guru berperan sebagai model yang menjadi fasilitator dan pembimbing yang melakukan scaffolding. Scaffolding adalah bimbingan yang diberikan oleh orang yang lebih tahu kepada orang yang kurang tahu atau belum tahu.(Shoimin, 2014: 153).

Peneliti lebih menekankan model pembelajaran kooperatif tipe Reciprocal Teaching ini karena cocok untuk keterampilan membaca, dengan pengajaran terbalik siswa belajar menjadi lebih efektif.Cara kerja model pembelajaran kooperatif tipe Reciprocal Teaching yaitu pengajaran diawali dari suatu pertanyaan yang jawabannya ada pada bahan bacaan yang dibagikan pada siswa, kemudian siswa bertindak seolah-olah jadi guru.Jadi, siswa yang berperan jadi guru, sedangkan guru seolah-olah jadi murid, dan murid yang memerankan sebagaimana layaknya menjadi seorang guru.Perhatian guru dalam pembelajaran terpusat bagaimana siswa belajar untuk mengingat, berpikir, dan memotivasi dirinya sendiri.

Berdasarkan penjelasan latar belakang yang telah dikemukakan di atas, maka hal inilah yang bisa mendorong penulis ingin melakukan penelitian tentang "Penerapan Model Pembelajaran Reciprocal Teaching Untuk Meningkatkan Keterampilan Membaca Intensif Pada Siswa Kelas VII MTs Darul Ulum Cepala Tahun Ajaran 2017/2018".Harapan penulis dengan menerapkan model pembelajaran Reciprocal Teaching siswa dapat meningkatkan hasil belajar menjadi lebih baik.

\section{METODE}

Jenis penelitian yang digunakan dalam penelitian ini adalah penelitian kuantitati. Menurut Sugiyono (2015:13) " metode kuantitatif adalah metode penelitian yang berlandaskan pada filsafat positivism, digunakan untuk meneliti populasi atau sampel tertentu, pengunpulan data menggunakan instrument penelitian , analisis data bersifat kuantitatif atau statistic dengan tujuan untuk menguji hipotesis yang telah diterapkan". Penelitian ini menggunakan penelitian pre-experimental design (nondesign). Adapun pentuk dari desain yang digunakan dalam penelitian yaitu, one-group pretest-postest design. Variabel adalahsesuatu hal yang berbentuk apa saja yang ditetapkan oleh peneliti untuk dipelajari sehingga diperoleh informasi tentang hal tersebut, kemudian ditarik kesimpulan (Sugiyono, 2015: 61). Adapapun populasi dalam penelitian ini adalah seluruh siswa kelas VII MTs Darul Ulum Cepala yang berjumlah 52 orang, yang terbagi atas 2 kelas. Sampel yang akan diambil dalam penelitian ini adalah kelas VII B dengan jumlah siswa sebanyak 28 orang. Teknik pengumpulan data dapat dilakukan dengan interview (wawancara), kuesioner (angket), observasi (pengamatan), dan gabungan ketiganya. .Adapun dalam penelitian ini teknik pengumpulan data yang digunakan adalah sebagai berikut. a) Teknik observasi langsung adalah observasi yang dilakukan tanpa perantara (secara langsung) terhadap objek yang diteliti". Artinya peneliti terjun langsung kelapangan untuk memperoleh datayang diperlukan secara objektif Mahmud (2011: 170). Nurgiyantoro (2014: 93) menyatakan, "Observasi 
merupakan cara untuk mendapat informasi dengan cara mengamati objek secara cermat dan terencana". b) Teknik pengukuran adalah cara mengumpulkan data yang bersifat kuantitatif untuk mengetahui tingkat atau derajat aspek tertentu dibandingkan dengan norma tertentu pula sebagai satuan ukur yang relevan" Nawawi (2012: 101). c) Teknik Komunikasi Tidak Langsung memperoleh data yang lebih akurat dalam penelitian ini penulis menggunakan teknik komunikasi tidak langsung. Nawawi (2012:101) menyatakan bahwa "Teknik komunikasi tidak langsung ialah cara mengumpulkan data yang dilakukan dengan mengadakan hubungan tidak langsung atau dengan perantaraan alat, baik berupa alat yang sudah tersedia maupun alat khusus yang dibuat untuk keperluan itu".

Teknik analisis data Untuk menjawab sub masalah pertama tentang peningkatan hasil belajar siswa dengan menggunakan model pembelajaran tipe reciprocal teaching dapat dirumuskan dengan rumus gain, Untuk menjawab sub masalah kedua tentang keterlaksanaan menggunakan skala Guttman, Untuk menjawab soal nomor tiga, tentang respon siswa pada model pembelajaran tipe reciprocal teaching dapat menggunakan rumus persentase. Dari pendapat di atas bahwa penulis terjun langsung ke tempat penelitian untuk mendapatkan data dan melihat kegiatan proses belajar mengajar yaitu MTs Darul Ulum Cepala.

\section{HASIL DAN PEMBAHASAN}

1. Peningkatan Hasil Belajar Siswa dengan Perhitungan Gain

Gain merupakan selisih antara nilai pretest dan posttest. Berdasarkan nilai pretest, posttest dan gain maka dapat dihitung sebagai berikut.

Tabel 1. Nilai Rata-rata Kelas Eksperimen

\begin{tabular}{lcc}
\hline \multirow{2}{*}{ Kelas } & \multicolumn{2}{c}{ Nilai Rata-rata } \\
\cline { 2 - 3 } Eksperimen (VIIB) & Pre-test & Post-test \\
\hline
\end{tabular}

Berdasarkan perhitungan di atas, dapat diperoleh nilai N-Gain sebesar 0,53 dengan kategori sedang. Dengan demikian, dapat disimpulkan bahwa menerapkan model pembelajaran reciprocal teaching pada materi membaca intensif mengungkapkan hal-hal yang dapat diteladani dari buku biografi yang dibaca secara intensif pada siswa kelas VII B MTs Darul Ulum Cepala dapat meningkatkan hasil belajar siswa.

2. Keterlaksanaan Model Pembelajaran Kooperatif Tipe Reciprocal Teaching

Observasi yang dilakukan dalam penelitian ini adalah untuk mengetahui keterlaksanaan pembelajaran dengan menggunakan model pembelajaran reciprocal teaching pada materi yang ada di dalam Rencana Pelaksanaan Pembelajarann (RPP). Observasi dilakukan dengan menggunakan lembar observasi yang telah disusun, dimana semua indikator yang diobservasi dalam penelitian ini dikembangkan dalam setiap pembelajaran. Adapun ringkasan data hasil dari observasi dapat dihitung sebagai berikut.

Tabel 2. Keterlaksanaan Pembelajaran

\begin{tabular}{ccc}
\hline $\begin{array}{c}\text { Penerapan Model Kooperatif Tipe } \\
\text { Reciprocal Teaching }\end{array}$ & Pertemuan I & Pertemuan II \\
\hline Jumlah & 100 & 83 \\
\hline Nilai Maxinmum & 112 & 96 \\
\hline Persentase & $89,28 \%$ & $86,45 \%$ \\
\hline Rata-Rata & \multicolumn{2}{c}{$87,865 \%$} \\
\hline
\end{tabular}

Berdasarkan data yang diperoleh di atas, didapatkan rata-rata keterlaksanaan sebesar 87,865\% dengan kriteria baik sekali. Dengan demikian, dapat disimpulkan bahwa keterlaksanaan 
pembelajaran pada materi membaca intensif mengungkapkan hal-hal yang dapat diteladani dari buku biografi yang dibaca secara intensif pada siswa kelas VII B MTs Darul Ulum Cepala sangat baik.

\section{Respon Belajar Siswa}

Respon diperoleh melalui penyebaran angket setelah kegiatan pembelajaran membaca intensif mengungkapkan hal-hal yang dapat diteladani dari buku biografi yang dibaca secara intensif selesai dilaksanakan. Setelah angket semua terkumpul, tahap selanjutnya peneliti melakukan tabulasi hasil data jawaban siswa terhadap tiap item pada angket. Adapun ringkasan data yang diperoleh dari penyebaranan angket sebagai berikut.

Berdasarkan hasil angket respon siswa, dapat diketahui bahwa untuk pernyataan positif sebagian besar siswa memberikan tanggapan atau respon setuju yang mencapai persentase 35,35\% sedangkan untuk pernyataan negatif sebagian besar siswa memberikan tanggapan atau respon tidak setuju yang mencapai persentase $33,57 \%$ terhadap 10 pernyataan mengenai penerapan model pembelajaran kooperatif tipe reciprocal teaching. keseluruhan respon siswa terhadap materi membaca intensif mengungkapkan hal-hal yang dapat diteladani dari buku biografi yang dibaca secara intensif dengan menerapkan model kooperatif tipe reciprocal teaching mencapai persentase $62,85 \%$ dengan kriteria baik.

Hasil Belajar Kemampuan Mengungkapkan Hal-Hal yang Dapat Diteladani dari Buku Biografi yang Dibaca Secara Intensif Berdasarkan hasil pengolahan data yang telah dilakukan, dapat diketahui hasil belajar siswa pada pembelajaran membaca intensif mengungkapkan hal-hal yang dapat diteladani dari buku biografi yang dibaca secara intensif dengan menerapkan model kooperatif tipe reciprocal teaching mengalami peningkatan.Hal ini terlihat dari hasil tes berupa soal yang memuat tiga indikator yaitu; (1) mampu mendata riwayat hidup tokoh, (2) mampu mendata keistimewaan tokoh, (3) mampu hal-hal yang dapat diteladani. Di lihat dari rumusan masalah hasil belajar siswa sebelum dan sesudah menggunakan model pembelajaran kooperatif tipe reciprocal teaching untuk meningkatkan keterampilan membaca intensif diperoleh nilai rata-ratapost-test yaitu 77,21 yang naik sebesar 25,93 dari nilai rata-rata pre-test yaitu 51,28. Selanjutnya dengan menggunakan perhitungan $\mathrm{N}$-gain diperoleh nilai gain sebesar 0,53 yang artinya terdapat peningkatan hasil belajar siswa hasil belajar siswa sebelum dan sesudah menggunakan model pembelajaran kooperatif tipe reciprocal teaching untuk meningkatkan keterampilan membaca intensif dalam mengungkapkan hal-hal yang dapat diteladani dari buku biografi dengan membaca intensif setelah diterapkannya model pembelajaran kooperatif tipe reciprocal teaching pada siswa kelas VII B MTs Darul Ulum Cepala dengan kategori sedang.

Hasil Observasi Keterlaksanaan Model Pembelajaran Kooperatif Tipe Reciprocal Teaching Berdasarkan hasil pengamatan terhadap keterlaksanaan pembelajaran dengan model pembelajaran kooperatif tipe reciprocal teaching, secara umum peneliti sudah melaksanakan serangkaian kegiatan pembelajaran yang menggunakan model pembelajaran kooperatif tipe reciprocal teaching pada materi membaca intensif dengan baik. Berdasarkan hasil perhitungan terhadap kegiatan yang diamati terbukti bahwa pada pertemuan pertama memperoleh rata-rata keterlaksanaan sebesar 100 atau 89,28\%. Sedangkan pada pertemuan kedua memperoleh rata-rata sebesar 83 atau $86,45 \%$. Secara keseluruhan keterlaksanaan model pembelajaran kooperatif tipe reciprocal teaching antara pertemuan pertama dan pertemuan kedua memiliki nilai rata-rata keterlaksanaan sebesar 87,865\% dengan kriteria baik sekali.

Hasil Angket Respon Proses pembelajaran dengan menggunakan model pembelajaran kooperatif tipe reciprocal teaching selesai siswa diberikan angket respon untuk mengetahui tanggapan siswa selama proses pembelajaran berlangsung. Angket respon siswa berupa angkettertutup, siswa hanya memilih dengan cara menceklis dari salah satu tanggapan yang telah disediakan.

Berdasarkan analisis hasil angket respon dapat diketahui bahwa untuk pernyataan positif siswa cenderung memberikan jawaban setuju terhadap penerapan model pembelajaran kooperatif tipe 
reciprocal teaching dapat termotivasi dan bermanfaat dalam pembelajaran, serta dapat berinteraksi sesama siswa. Sedangkan untuk pernyataan negatif siswa cenderung memberikan jawaban tidak setuju bahwa dengan penerapan model pembelajaran kooperatif tipe reciprocal teaching dapat membuat belajar menjadi jenuh, kurang percaya diri, terbebani, dan kurang mengerti dengan materi yang telah diajarkan.

Berdasarkan pernyataan tersebut dapat disimpulkan bahwa pembelajaran dengan menggunakan model kooperatif tipe reciprocal teaching dalam berdiskusi atau saat mengerjakan soal, membuat siswa percaya diri dalam berperan sebagai guru dan memberikan komentar juga dengan penerapan model pembelajaran kooperatif tipe reciprocal teaching dapat membuat siswa termotivasi, berinteraksi sesama siswa, dan menjadikan pembelajaran lebih bermanfaat. Secara keseluruhan respon siswa terhadap pembelajaran membaca intensif dalam mengungkapkan hal-hal yang dapat diteladani dari buku biografi dengan membaca intensif model kooperatif tipe reciprocal teaching termasuk dalam kategori baik yang memperoleh persentase respon siswa sebesar $67,85 \%$.

\section{KESIMPULAN DAN SARAN}

Berdasarkan hasil pengolahan data peneliti yang dilakukan, secara umum dapat disimpulkan bahwa terdapat peningkatan hasil belajar siswa dalam dalam mengungkapkan hal-hal yang dapat diteladani dari buku biografi dengan membaca intensif melalui penerapan model pembelajaran kooperatif tipe reciprocal teaching pada siswa kelas VII B MTs Darul Ulum Cepala tahun ajaran 2017/2018, secara khusus dapat disimpulkan beberapa hasil sebagai berikut.

Di lihat dari rumusan masalah hasil belajar siswa sebelum dan sesudah menggunakan model pembelajaran kooperatif tipe reciprocal teaching untuk meningkatkan keterampilan membaca intensif diperoleh nilai rata-ratapost-test yaitu 77,21 yang naik sebesar 25,93 dari nilai rata-rata pre-test yaitu 51,28 . Selanjutnya dengan menggunakan perhitungan $N$-gain diperoleh nilai gain sebesar 0,53 yang artinyaterdapat peningkatan hasil belajar siswa dalam dalam mengungkapkan hal-hal yang dapat diteladani dari buku biografi dengan membaca intensif antara sebelum dan sesudah diterapkan model pembelajaran kooperatif tipe reciprocal teaching dengan rata-rata nilai $N$-gain sebesar 0,53 dengan kategori sedang.

Berdasarkan data yang diperoleh di atas, terdapat rata-rata keterlaksanaan pertemuan pertamasebesar $89,28 \%$, sedangkan rata-rata keterlaksanaan pertemuan kedua sebesar $86,45 \%$. Dengan demikian, dapat disimpulkan bahwa keterlaksanaan model pembelajaran kooperatif tipe reciprocal teaching dalam pembelajaran membaca intensif termasuk dalam kategori baik sekali dengan perolehan persentase keterlaksanaan sebesar $87,865 \%$.

Respon belajar siswa setelah diterapkannya model pembelajaran kooperatif tipe reciprocal teaching untuk meningkatkan keterampilan membaca intensif termasuk dalam kriteria baik dengan persentase mencapai $62,85 \%$.

\section{SARAN}

Untuk meningkatkan hasil belajar siswa diperlukan suatu inovasi dalam proses pembelajaran, salah satunya adalah dapat menggunakan model pembelajaran kooperatif tipe reciprocal teaching karena model ini memberikan kesempatan pada siswa berperan sebagai guru di depan rekannya dan dapat menambah kepercayaan diri pada siswa serta membuat siswa berinteraksi dengan rekannya dalam pembelajaran untuk berbagi ilmu dan rasa tanggung jawab setiap individu dalam kelompoknya. Sehingga siswa tidak jenuh saat mengikuti proses pembelajaran serta dapat memahami materi yang disampaikan. 


\section{DAFTAR PUSTAKA}

Dalman.(2013). Keterampilan Membaca. Jakarta:PT Bumi Aksara.

Huda, Miftahul. 2014. Cooperative Learning. Yogyakarta: Pelajar.

Mahmud.2011. MetodologiPenelitianPendidikan. Jakarta: RinekaCipta.

Nawawi, Hadari. 2012. MetodePenelitianBidangSosial.Yogyakarta.:GadjahMada University Presis.

Ngalimun. 2016. Strategi danModel Pembelajaran. Yogyakarta: AswajaPressindo.Rosdakarya.

Nurgiyantoro, Burhan. 2014. Penilaian Pembelajaran Bahasa Berbasis Kompetensi. Yogyakarta:BPFE-Yogyakarta.

Prasetyo, MuhBagus.2015. Penerapan Model Pembelajaran Reciprocal Teaching Untuk Meningkatkan Kemampuan Membaca Pemahaman. Pada Jurnal PGSD FKIP Universitas Sebelas Maret Surakarta. Diakses 1 Maret 2017 Tarigan, Henry Guntur. 2008. MembacaSebagaiSuatuKeterampilanBerbahasa. Bandung: Angkasa.

Saddhono.2012. Meningkatkan Keterampilan Berbahasa Indonesia. Bandung: Karya Putra Darwati.

Shoimin, Aris. 2014. 68 Model Pembelajaran Inovatif dalam Kurikulum 2013. Yogyakarta : Ar- Ruzz Media.

Sugiyono.2015. MetodePenelitianPendidikan (Pendekatan Kuantitaif Kualitatif, dan $R \& D$ ). Bandung: Alfabeta.

Tarigan, Henry Guntur. 2008. Membaca Sebagai Suatu Keterampilan Berbahasa. Bandung: Angkasa. 